MINERALOGIA, 49, No 1-4: 47-65 (2018)

Original paper

\title{
Trace elements and REE enrichment at Seboah Hill, SW Egypt
}

\author{
Kamaleldin M. Hassan ${ }^{1 *}$ \\ ${ }^{1}$ Department of Radioactive Sedimentary Deposits, Research Sector, Nuclear Materials Authority, Qattamia, \\ Cairo, Egypt \\ * Corresponding author \\ e-mail:egy100@yahoo.com
}

Received: December 3, 2017

Received in revised form: May 15, 2018

Accepted: July 30, 2018

Available online: September 14, 2018

\begin{abstract}
Seboah Hill - a small body of peralkaline granite $\left(<0.1 \mathrm{~km}^{2}\right)$ in south-western Egypt containing aegirine minerals \pm magnesiohornblende \pm riebeckite, cut by dikes of riebeckite-aegirine rhyolite, and exhibiting high radioactivity in veins of K-feldspar-aegirine-chalcedony-quartz \pm trace hematite \pm trace goethite was sampled and analyzed using inductively coupled plasma methods. Whole-rock chemical compositions of 5 granite, 3-rhyolitedike and 10 radioactive vein samples are presented. Of special significance is the enrichment of trace elements and rare earth elements (REE) in the radioactive veins. These include up to $6081 \mathrm{ppm} \mathrm{Zr}, 4252 \mathrm{ppm} \mathrm{Ce}, 1514 \mathrm{ppm} \mathrm{Nd}$, 1433 ppm La, 1233 ppm Nb, 875 ppm Y, 388 ppm Pr, 350 ppm Th, 222 ppm Sm, 189 ppm Gd, 159 ppm Dy, $153 \mathrm{ppm} \mathrm{Hf}, 83 \mathrm{ppm}$ Er, $76 \mathrm{ppm} \mathrm{Yb}$ and $58 \mathrm{ppm} \mathrm{U}$. The chondrite-normalized patterns of REE in all samples show only limited variation and have negative europium $(\mathrm{Eu})$ anomalies. These findings suggest that the sources of the REE are genetically related. Values of the Eu anomalies vary from $0.38-0.41$ for the radioactive veins, 0.39 0.53 for the granite and 0.31-0.44 for the rhyolite dikes. Eu variations are consistent for different paragentic stages.
\end{abstract}

Key-words: Oversaturated peralkaline rocks, trace elements, REE, thorium/uranium anomalies

\section{Introduction}

A peralkaline magma is so enriched in soda and potash (alkalis) with respect to alumina that the alumina content is insufficient to accommodate all alkalis in feldspars and micas (Mc Birney 1984). The excess alkalis enter pyroxene, amphibole, and other minerals in which iron and titanium take the place of aluminum as exemplified in Table 1. In the CIPW norms of peralkaline igneous rocks, part of the soda is assigned to normative acmite (Ac) and, in rocks very rich in $\mathrm{Na}$ or $\mathrm{K}$, to sodium or potassium metasilicates $\left(\mathrm{Ns}-\mathrm{Na}_{2} \mathrm{SiO}_{3}\right.$ and 
$\mathrm{Ks}-\mathrm{K}_{2} \mathrm{SiO}_{3}$, respectively). These alkali enrichments do not necessarily imply a decrease or increase in silica; peralkaline igneous rocks may be oversaturated, saturated, or undersaturated with silica. Oversaturated peralkaline igneous commonly occur in ring complexes and dike-like intrusions rocks and, though tending to be highly silicic, generally do not show evidence of being strongly differentiated. They are depleted in elements such as $\mathrm{Mg}, \mathrm{Ca}, \mathrm{Cr}, \mathrm{V}, \mathrm{Sc}$ and $\mathrm{Ni}$, and are typically enriched in rare metals (e.g. REE, $\mathrm{U}, \mathrm{Th}, \mathrm{Nb}$, $\mathrm{Y}, \mathrm{Zr}, \mathrm{Hf}, \mathrm{Ta}$ ) due to the crystallization of granite magma enriched in volatiles and trace elements, or the metasomatic transformation of preexisting granitic rocks (i.e. Whalen et al. 1987; Jain et al. 1996; Das et al. 2016; Philpotts et al. 1996; Abdel Monem, El-Afandy 1997; Sorokhtina et al. 2012; Singh et al. 2009; Andreeva 2016).

TABLE 1

Important minerals in peralkaline igneous rocks as mentioned in the text.

\begin{tabular}{ll}
\hline Aegirine or Acmite & $\mathrm{NaFe}^{3+} \mathrm{Si}_{2} \mathrm{O}_{6}$ \\
Aegirine-augite & $\mathrm{CaNaMgFe}^{2+} \mathrm{Fe}^{3+} \mathrm{Si}_{2} \mathrm{O}_{6}$ \\
Riebeckite & $\mathrm{Na}_{2} \mathrm{Fe}^{2+}{ }_{3} \mathrm{Fe}^{3+}{ }_{2} \mathrm{Si}_{8} \mathrm{O}_{22}(\mathrm{OH})_{2}$ \\
Arvedsonite & $\left(\mathrm{Na}_{3} \mathrm{Fe}^{2+}{ }_{4} \mathrm{Fe}^{3+}\right) \mathrm{Si}_{8} \mathrm{O}_{22}(\mathrm{OH})_{2}$ \\
Aenigmatite & $\left(\mathrm{NaCa}_{4}\left(\mathrm{Fe}^{2+} \mathrm{TiMg}_{12} \mathrm{Si}_{12} \mathrm{O}_{40}\right.\right.$ \\
Eudialyte & $\mathrm{Na}_{15} \mathrm{Ca}_{6} \mathrm{Fe}_{3} \mathrm{Zr}_{3} \mathrm{Si}_{26} \mathrm{O}_{72}(\mathrm{OH})_{4} \mathrm{Cl}$ \\
Elpidite & $\mathrm{Na}_{2} \mathrm{ZrSi}_{6} \mathrm{O}_{15} \cdot 3 \mathrm{H} 2 \mathrm{O}$ \\
Dalyite & $\mathrm{K}_{2} \mathrm{ZrSi}_{6} \mathrm{O}_{15}$ \\
Astrophyllite & $\mathrm{K}_{3} \mathrm{Fe}^{2+}{ }_{7} \mathrm{Ti}_{2} \mathrm{Si}_{8} \mathrm{O}_{26}(\mathrm{OH})_{5}$ \\
Armstrogite & $\mathrm{CaZrSi}_{6} \mathrm{O}_{15} \cdot 3 \mathrm{H}_{2} \mathrm{O}$, \\
Gittinsite & $\mathrm{CaZrSi}_{2} \mathrm{O}_{7}$ \\
\hline
\end{tabular}

Seboah Hill (Fig. 1), a body of peralkaline granite $\left(\sim 70000 \mathrm{~m}^{2}\right)$ rising above a Paleozoic to Mesozoic terrestrial sandstone known as the Nubia Formation in south-western Egypt, consists of quartz, K-feldspar, aegirine, and albite \pm aegirine-augite \pm magnesiohornblende. It is cut by a few dikes of rhyolite with quartz, potash feldspar, aegirine, albite, and riebeckite (Hassan 2009a). The granite contains several zones of fractures filled with finegrained veins comprising chalcedony, quartz, aegirine, and potash feldspar \pm minor iron (ferric)-oxide phases. These red, brown and green veins range in thickness from a few centimeters to $0.5 \mathrm{~m}$. Though their total field gamma-ray radiation is up to $\sim 10$ orders of magnitude more than the general radiation background, they lack any obvious radioactive mineralization. The radiation is due to thorium $(\mathrm{Th})$ and uranium $(\mathrm{U})$, with equivalent concentrations of 240-387 and 40-51 ppm, respectively. The Th and $U$ appear to reside in the aegirine and in trace rare-metal complexes (Hassan 2005). The radioactive veins are high in iron (to $\sim 16 \mathrm{wt} \% \mathrm{Fe}$ ). The extent of oxidation of the iron is $100 \%$ (Hassan 2010). The iron enrichment and strong oxidation point to an environment of high oxygen fugacity. 


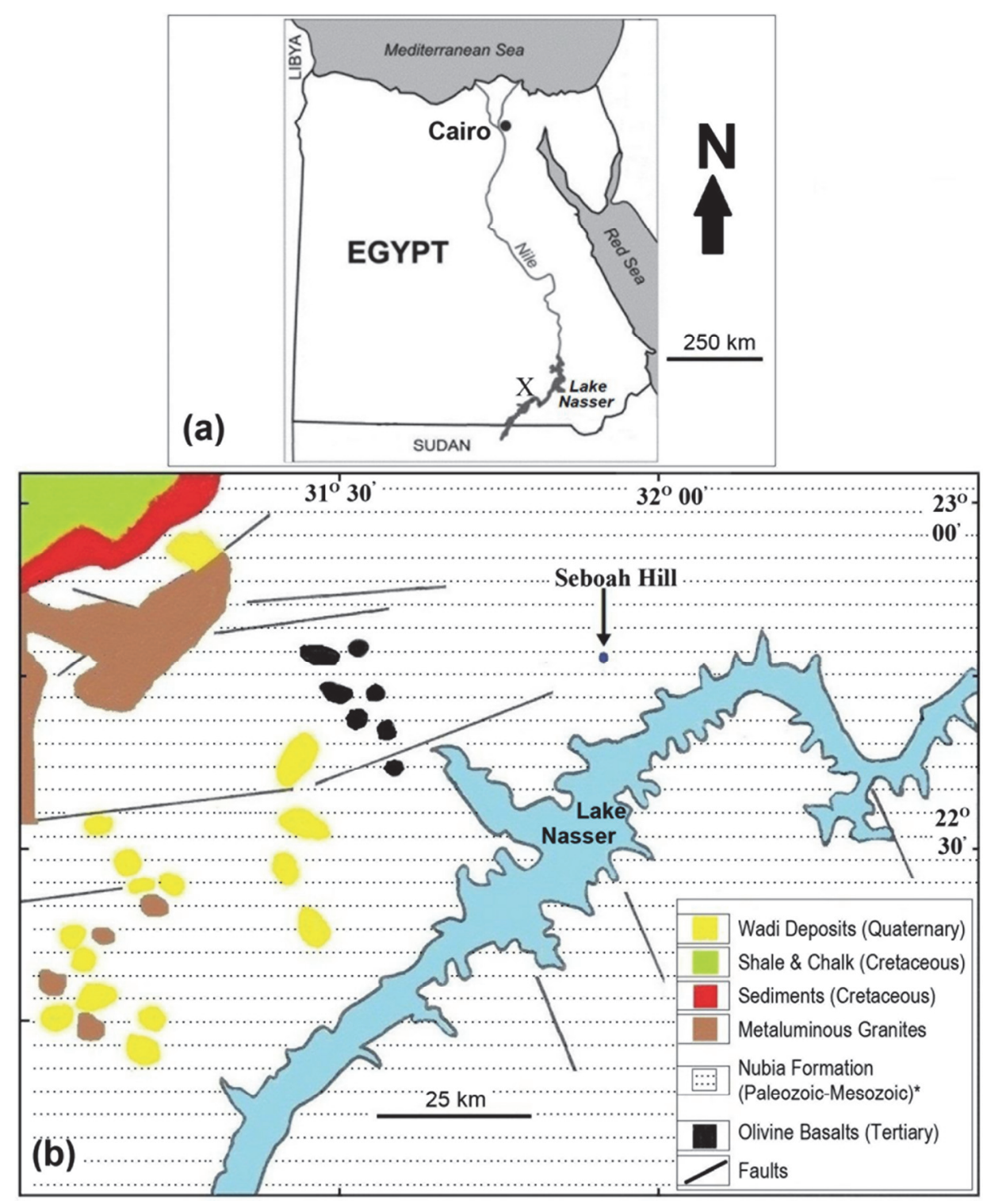

Fig. 1. (a) Location of study site (X). (b) Geological map of south Western Desert, Egypt, revised from Egyptian Geological Survey and Mining Authority (1981). *The age of the Nubia Formation (Paleozoic-Mesozoic) is from Baioumy et al. (2003).

Samples of the granite, rhyolite, and radioactive veins from Seboah Hill were analyzed for 9 major elements ( $\mathrm{Ti}, \mathrm{Al}, \Sigma \mathrm{Fe}, \mathrm{Mn}, \mathrm{Mg}, \mathrm{Ca}, \mathrm{Na}, \mathrm{K}, \mathrm{P})$ and 29 trace-elements (Ba, Be, Co, Cs, Ga, Rb, Sr, V, Y, Nb, Ta, Zr, Hf, Th, U, La, Ce, Pr, Nd, Sm, Eu, Gd, Tb, Dy, Ho, $\mathrm{Er}, \mathrm{Tm}, \mathrm{Yb}, \mathrm{Lu}$ ) using inductively coupled plasma mass-spectrometry. The geochemical signatures extracted from the whole-rock chemical composition of the samples should 
provide petrogenetic insights into the rare-element enrichment in the peralkaline granite and its geochemical associates in Egypt and elsewhere.

\section{Methods}

For this study, 5 granite (G1-G5), 3 rhyolite (R1-R3), and 10 radioactive vein (V1-V10) samples were collected from Seboah Hill. Any weathered parts were removed. Some of the samples are characterized by brown colors, others by yellow colors, and still others by green or olive colors (Table 2). The results of bulk X-ray diffraction analysis (XRD) of the samples are summarized in Table 2. In the granite, in addition to albite, potash feldspar and

TABLE 2

Colors and mineral compositions of samples from Seboah Hill

\begin{tabular}{|c|c|c|}
\hline Sample & Munsell color & Mineralogy (trace components in parenthesis) \\
\hline \multicolumn{3}{|c|}{$\begin{array}{l}\text { Radioactive } \\
\text { veins }\end{array}$} \\
\hline V1 & moderate greenish yellow (10Y $7 / 4)$ & quartz, aegirine, sanidine, orthoclase \\
\hline V2 & pale olive (10Y 6/2) & quartz, aegirine, sanidine, orthoclase \\
\hline V3 & pale olive (10Y $6 / 2)$ & quartz, aegirine, sanidine, orthoclase \\
\hline V4 & moderate reddish brown $(10 \mathrm{Y} 4 / 6)$ & quartz, aegirine, sanidine, orthoclase \\
\hline V5 & moderate reddish brown (10Y 4/6) & quartz, aegirine, sanidine, orthoclase \\
\hline V6 & moderate reddish brown $(10 \mathrm{Y} 4 / 6)$ & $\begin{array}{l}\text { quartz, aegirine, sanidine, orthoclase, } \\
\text { (hematite, goethite) }\end{array}$ \\
\hline V7 & moderate reddish brown $(10 \mathrm{Y} 4 / 6)$ & $\begin{array}{l}\text { quartz, aegirine, sanidine, orthoclase, } \\
\text { (hematite, goethite) }\end{array}$ \\
\hline V8 & moderate reddish brown $(10 \mathrm{Y} 4 / 6)$ & $\begin{array}{l}\text { quartz, aegirine, sanidine, orthoclase, } \\
\text { (hematite, goethite) }\end{array}$ \\
\hline V9 & moderate reddish orange (10R 6/6) & $\begin{array}{l}\text { quartz, aegirine, sanidine, orthoclase, } \\
\text { (hematite, goethite) }\end{array}$ \\
\hline V10 & moderate reddish orange (10R 6/6) & $\begin{array}{l}\text { quartz, aegirine, sanidine, orthoclase, } \\
\text { (hematite, goethite) }\end{array}$ \\
\hline \multicolumn{3}{|l|}{ Granite } \\
\hline G1 & moderate reddish brown $(10 \mathrm{R} 4 / 6)$ & $\begin{array}{l}\text { potash feldspar, quartz, aegirine-augite, } \\
\text { aegirine, albite }\end{array}$ \\
\hline G2 & pale yellowish brown (10YR 6/2) & $\begin{array}{l}\text { potash feldspar, quartz, aegirine, aegirine- } \\
\text { augite, albite }\end{array}$ \\
\hline G3 & pale yellowish brown (10YR 6/2) & $\begin{array}{l}\text { potash feldspar, quartz, aegirine-augite, } \\
\text { aegirine, albite, magnesiohornblende }\end{array}$ \\
\hline G4 & light brown (5YR 5/6) & $\begin{array}{l}\text { potash feldspar, quartz, aegirine-augite, } \\
\text { aegirine, albite, magnesiohornblende }\end{array}$ \\
\hline G5 & light brown (5YR 5/6) & $\begin{array}{l}\text { potash feldspar, quartz, aegirine-augite, } \\
\text { aegirine, albite, magnesiohornblende }\end{array}$ \\
\hline \multicolumn{3}{|r|}{ 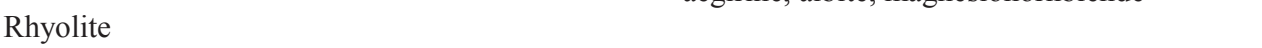 } \\
\hline $\mathrm{R} 1$ & dusty yellow green ( 5 GY 5/2) & $\begin{array}{l}\text { quartz, potash feldspar, aegirine, albite, } \\
\text { riebeckite }\end{array}$ \\
\hline R2 & dusty yellow green (5GY 5/2) & $\begin{array}{l}\text { quartz, potash feldspar, aegirine, albite, } \\
\text { riebeckite }\end{array}$ \\
\hline R3 & pale yellowish orange (10 YR 8/6) & $\begin{array}{l}\text { quartz, potash feldspar, aegirine, albite, } \\
\text { riebeckite }\end{array}$ \\
\hline
\end{tabular}


TABLE 3

Experimental analyses of reference standards and of blank samples.

\begin{tabular}{|c|c|c|c|c|c|c|c|c|c|c|}
\hline & \multicolumn{2}{|c|}{$\begin{array}{l}\text { STD } \\
\text { OREAS24P }\end{array}$} & \multicolumn{2}{|c|}{$\begin{array}{l}\text { STD } \\
\text { OREAS45E }\end{array}$} & \multicolumn{2}{|c|}{ STD SO-18 } & \multicolumn{2}{|c|}{$\begin{array}{l}\text { STD } \\
\text { DOLOMITE-2 }\end{array}$} & Blank-1 & Blank-2 \\
\hline & 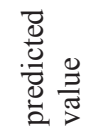 & 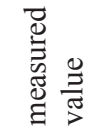 & 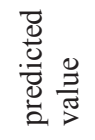 & 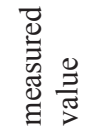 & 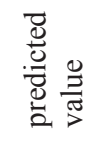 & 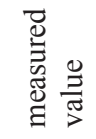 & 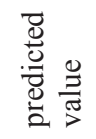 & 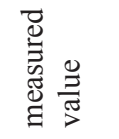 & 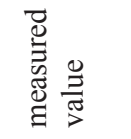 & 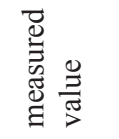 \\
\hline $\mathrm{Ti}(\mathrm{wt} \%)$ & 1.1 & 1.07 & 0.56 & 0.481 & & & & & $<0.001$ & \\
\hline $\mathrm{Al}$ & 7.66 & 7.61 & 6.78 & 6.56 & & & & & 0.05 & \\
\hline $\mathrm{Fe}$ & 7.53 & 7.27 & 24.12 & 22.91 & & & & & $<0.01$ & \\
\hline $\mathrm{Mn}$ & 0.11 & 0.11 & 0.055 & 0.05 & & & & & 0.0002 & \\
\hline $\mathrm{Mg}$ & 4.13 & 4.03 & 0.156 & 0.15 & & & & & $<0.01$ & \\
\hline $\mathrm{Ca}$ & 5.83 & 5.68 & 0.065 & 0.07 & & & & & $<0.01$ & \\
\hline $\mathrm{Na}$ & 2.34 & 2.47 & 0.059 & 0.051 & & & & & $<0.001$ & \\
\hline K & 0.7 & 0.63 & 0.324 & 0.3 & & & & & $<0.01$ & \\
\hline $\mathrm{P}$ & 0.136 & 0.124 & 0.034 & 0.03 & & & & & 0.001 & \\
\hline LOI & & & & & & & 49.9 & 49.9 & & \\
\hline $\mathrm{Ba}(\mathrm{ppm})$ & 285 & 275 & 252 & 226 & 514 & 522 & & & 1 & $<1$ \\
\hline $\mathrm{Be}$ & & 1 & & $<1$ & 1 & 1 & & & $<1$ & $<1$ \\
\hline $\mathrm{Co}$ & 44 & 44.6 & 57 & 53 & 26.2 & 25.7 & & & $<0.2$ & $<0.2$ \\
\hline Cs & & & & & 7.1 & 6.8 & & & & $<0.1$ \\
\hline $\mathrm{Ga}$ & & & & & 17.6 & 16.7 & & & & $<0.5$ \\
\hline $\mathrm{Rb}$ & 22.4 & 20.5 & 21.2 & 18.7 & 28.7 & 27.6 & & & 0.5 & $<0.1$ \\
\hline $\mathrm{Sr}$ & 403 & 389 & 15.9 & 11 & 407.4 & 386.6 & & & $<1$ & $<0.5$ \\
\hline V & 158 & 160 & 322 & 313 & 200 & 200 & & & $<1$ & $<8$ \\
\hline Y & 21.3 & 21.9 & 8.28 & 6.7 & 31 & 29.9 & & & 0.2 & $<0.1$ \\
\hline $\mathrm{Nb}$ & 21 & 18.6 & 6.8 & 5.7 & 21.3 & 21.6 & & & 0.2 & 1 \\
\hline $\mathrm{Ta}$ & 1.04 & 1.2 & 0.56 & 0.6 & 7.4 & 7.1 & & & $<0.1$ & 0.2 \\
\hline $\mathrm{Zr}$ & 141 & 132.4 & 110 & 89.4 & 280 & 286.3 & & & 0.3 & 0.2 \\
\hline Hf & 3.6 & 3.5 & 3.11 & 2.7 & 9.8 & 9.7 & & & $<0.1$ & $<0.1$ \\
\hline Th & 2.85 & 2.9 & 12.9 & 11.8 & 9.9 & 10 & & & $<0.1$ & $<0.2$ \\
\hline $\mathrm{U}$ & 0.75 & 0.7 & 2.41 & 2.2 & 16.4 & 14.6 & & & $<0.1$ & $<0.1$ \\
\hline $\mathrm{La}$ & 17.4 & 18.2 & 11 & 8.4 & 13.3 & 12.5 & & & 0.4 & $<0.1$ \\
\hline $\mathrm{Ce}$ & 37.6 & 37 & 23.5 & 20 & 27.1 & 24.5 & & & $<1$ & $<0.1$ \\
\hline $\operatorname{Pr}$ & & & & & 3.45 & 3.36 & & & & $<0.02$ \\
\hline $\mathrm{Nd}$ & & & & & 14 & 13.3 & & & & $<0.3$ \\
\hline $\mathrm{Sm}$ & & & & & 3 & 2.85 & & & & $<0.05$ \\
\hline $\mathrm{Eu}$ & & & & & 0.89 & 0.85 & & & & $<0.02$ \\
\hline $\mathrm{Gd}$ & & & & & 2.93 & 2.87 & & & & $<0.05$ \\
\hline $\mathrm{Tb}$ & & & & & 0.44 & 0.45 & & & & $<0.01$ \\
\hline Dy & & & & & 3 & 2.7 & & & & $<0.05$ \\
\hline Ho & & & & & 0.62 & 0.57 & & & & $<0.02$ \\
\hline $\mathrm{Er}$ & & & & & 1.84 & 1.69 & & & & $<0.03$ \\
\hline $\mathrm{Tm}$ & & & & & 0.27 & 0.25 & & & & $<0.01$ \\
\hline $\mathrm{Yb}$ & & & & & 1.79 & 1.67 & & & & $<0.05$ \\
\hline $\mathrm{Lu}$ & & & & & 0.27 & 0.28 & & & & $<0.01$ \\
\hline
\end{tabular}


quartz, aegirine-augite and aegirine occur as the major Fe minerals: they are associated with minor amounts of magnesiohornblende in G3, G4, and G5. The rhyolite consists of quartz, potash feldspar, albite, aegirine and riebeckite. In the radioactive veins, quartz and aegirine were by identified by XRD as the major components. They are associated with small amounts of potash feldspar. Traces of hematite and goethite occur in V6, V7, V8, V9 and V10. No carbonate was identified in any sample.

Thin sections of the samples were studied using an Olympus BX41 polarizing microscope at the Nuclear Materials Authority, Qattamia, Cairo, Egypt. Loss-on-ignition (LOI) and whole-rock chemical analyses were made at Bureau Veritas Commodities Canada Ltd., Vancouver, Canada, using analytical procedures described by Hassan (2017). The LOI was determined in 13 bulk samples by igniting dried, powdered, samples $(1 \mathrm{~g})$ in a furnace at $1000^{\circ} \mathrm{C}$. For whole-rock major-chemical analysis, aliquots of 13 bulk samples weighing $0.25 \mathrm{~g}$ each were digested in a mixture of $\mathrm{H}_{2} \mathrm{O}-\mathrm{HF}-\mathrm{HClO}_{4}-\mathrm{HNO}_{3}$ and dried. The dissolved residue was taken up in $\sim 20 \% \mathrm{HCl}$ and was then heated using a mixing hot block. After cooling, the solutions were brought to volume with dilute $\mathrm{HCl}$ and then analyzed for 9 major elements (Ti, Al, $\Sigma \mathrm{Fe}, \mathrm{Mn}, \mathrm{Mg}, \mathrm{Ca}, \mathrm{Na}, \mathrm{K}, \mathrm{P}$ ) using a Spectro Ciros inductively coupled plasma-emission spectroscope (ICP-ES) and a Perkin Elan inductively coupled plasma-mass spectrometer (ICP-MS). For whole-rock minor-chemical analysis, aliquots of 18 bulk-samples $(0.20 \mathrm{~g})$ were each mixed with a flux of $\mathrm{LiBO}_{2} / \mathrm{Li}_{2} \mathrm{~B}_{4} \mathrm{O}_{7}$ flux, and then fused in a furnace at $1050^{\circ} \mathrm{C}$. The cooled bead was dissolved in a $5 \%$ nitric acid solution, shaken to dissolve, and then analyzed by the ICP-ES and ICP-MS to measure concentrations of 29-trace elements (Ba, Be, Co, Cs, Ga, Rb, Sr, V, Y, Nb, Ta, Zr, Hf, Th, U, La, Ce, Pr, Nd, Sm, Eu, Gd, Tb, Dy, Ho, Er, Tm, Yb, Lu). The validity of the LOI and ICP-ES/ICP-MS data was guaranteed by the use reference materials (STD OREAS45E, STD OREAS24P, STD SO-18, STD DOLOMITE-2), analysis of reagent blanks (Table 3), and replicate analyses. The analytical error (standard deviation determined from different sample duplicates) was $<4 \%$ for LOI and for the elements, except for Be $(30 \%)$ and Co $(\sim 12 \%)$. The silica content of each sample was determined by: [100 - (wt \% major-element oxides + wt $\%$ trace elements $+\mathrm{wt} \% \mathrm{LOI})]=\mathrm{wt} \% \mathrm{SiO}_{2}$.

\section{Results and discussion}

\subsection{Petrography}

The radioactive-vein samples are holocrystalline, subhedral, granular rocks that often contain felsic phyenocrysts and silica cavities. They consist of chalcedony, quartz, aegirine, and K-feldspars (Fig. 2). The feldspars (mainly sanidine) occur as subhedral phyenocrysts, and as fine-medium grained cracked and interlocked grains that are slightly altered to microcrystalline silica and kaolinite. Chalcedony (fibrous quartz) occurs as spherulities, and as fine aggregates forming pockets and microveinlets: it is either opaque or transparent, and usually has varying colors (red, yellow or brown) due mainly to Fe impurities. Quartz is present as coarse-grained anhedral-subhedral phenocrysts and as fine-medium interstitial grains. Aegirine, ranging in size from tiny, acicular, medium to long prisms, usually forms radiating aggregates and may be included poikilitically within large quartz crystals. The 
aegirine crystals are slightly altered along the cleavage planes where leached iron oxides
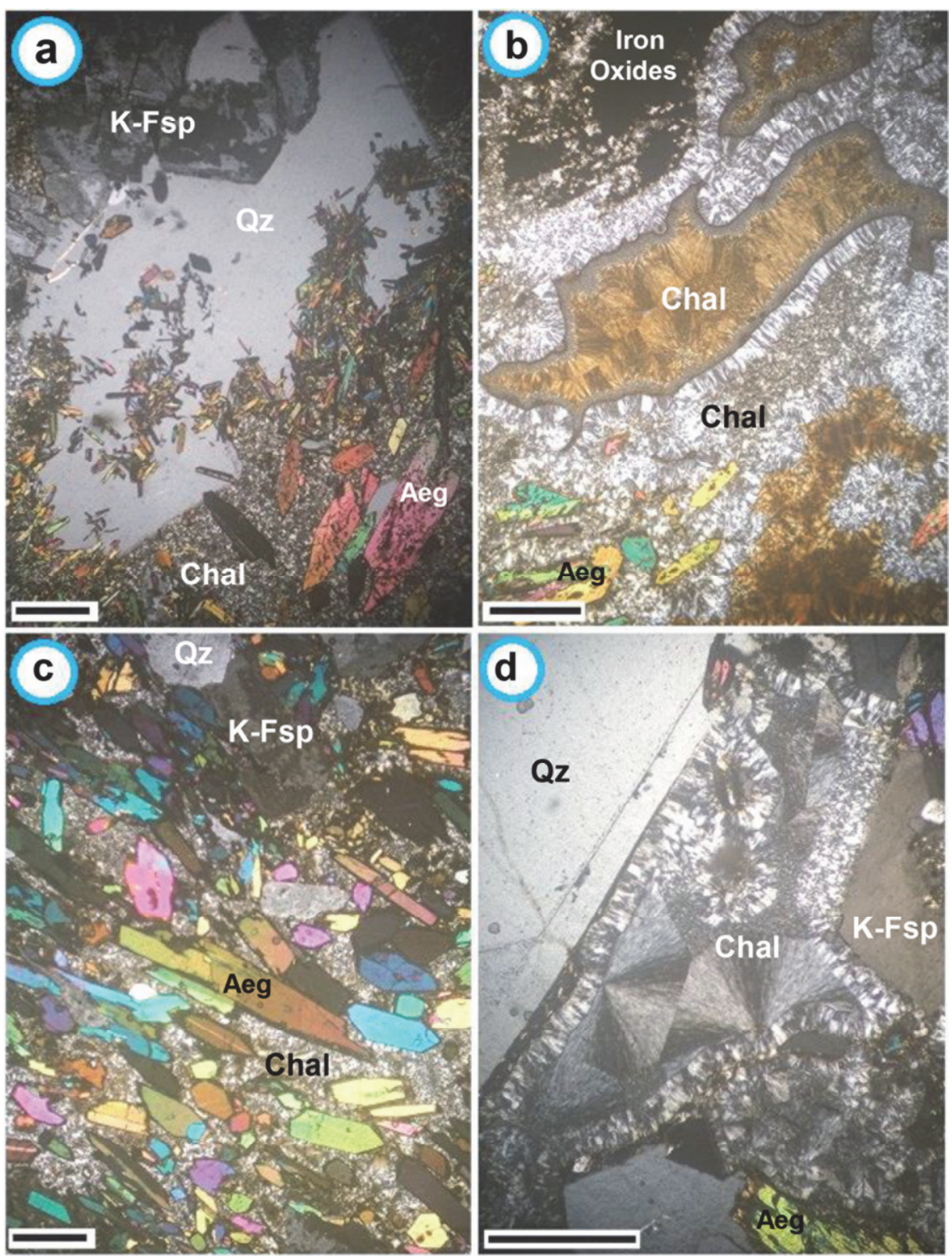

Fig. 2. Photomicrographs taken under crossed polars for radioactive vein samples V5 (a, b), V6 (c), and V7 (d) from Seboah Hill (scale bar $=500$ micrometers). (a) View of V5 shows aegirine (Aeg) prisms in a groundmass of chalcedony (Chal). The other mineral present is potash feldspar (K-Fsp) slightly altered to kaolinite and quartz (Qz). (b) Another view of V5 showing opaque minerals (iron oxides), aegirine prisms, and cavities filled with chalcedony with brown colors due to the presence of iron. (c) Photomicrograph of V6 showing aegirine prisms with some quartz and K-feldspar in 
a chalcedony groundmass. (d) A fissure filled with wedge-shaped twinned chalcedony in V7. The two other minerals present are quartz and aegirine.

have precipitated along them. The preserved spheulitic texture in these radioactive veins may indicate that the original material, which may have been late-injected melt or residualinterstial melt, was devitrified at high temperature, resulting in a mixture of spherulites and crystals (Hassan 2010).

The granite of Seboah Hill is coarse grained, composed mainly of quartz, potash feldspar, and mafic minerals (Fig. 3a-c). Quartz occurs as coarse-grained crystals with interlocking sutured edges and exhibits wavy extinction. The $\mathrm{K}$-feldspar is represented by orthoclase and/or perthite. Feldspar crystals are slightly altered to kaolinite. Mafic minerals include aegirine, aegirine-augite, and hornblende. Some aegirine-augite crystals are altered to amphiboles (riebeckite and hornblende), while others are altered along cleavage planes marked by iron oxides.

The Seboah rhyolite is fine grained, holocrystalline, and consists of elongated spheroids with a radial fibrous structure. These spherulites are mostly feldspars with interstitial quartz and a matrix scattered with aegirine and riebeckite (Fig. 3d, e). Quartz is also present as medium-coarse grained anhydral-subhedral phenocrysts.

\subsection{Major-element composition}

Results of loss-on-ignition (LOI) and major-element analyses of the radioactive vein, granite, and rhyolite samples from Seboah Hill are listed in Table 4, along with $\mathrm{Fe}^{3+} / \sum \mathrm{Fe}$ of the samples from Hassan (2009b 2010). The LOI values ranging from $0.3-2.0 \mathrm{wt} \%$ represent the loss of $\mathrm{H}_{2} \mathrm{O}$ in the main. In the radioactive vein samples, contents (wt\%) of major elements are, in decreasing order, $\mathrm{SiO}_{2}=73.0-77.8, \mathrm{Fe}_{2} \mathrm{O}_{3}=12.4-15.3, \mathrm{Na}_{2} \mathrm{O}=3.01-5.9$, $\mathrm{Al}_{2} \mathrm{O}_{3}=1.6-2.8, \mathrm{~K}_{2} \mathrm{O}=1.05-2.2, \mathrm{CaO}=0.14-0.3, \mathrm{Ti}_{2} \mathrm{O}=0.18-0.33, \mathrm{MnO}=0.19-0.25, \mathrm{P}_{2} \mathrm{O}_{5}$ $=0.0-0.1, \mathrm{MgO}=0.03-0.07$. The granite and rhyolite samples, on the other hand, contain 69.7-72.2 $\mathrm{wt}_{0} \mathrm{SiO}_{2}, 7.5-10.2 \mathrm{Fe}_{2} \mathrm{O}_{3}, 7.08-9.9 \mathrm{Al}_{2} \mathrm{O}_{3}, 3.78-5.56 \mathrm{Na}_{2} \mathrm{O}, 4.51-5.06 \mathrm{~K}_{2} \mathrm{O}$, and $0.28-0.5 \mathrm{TiO}_{2}$. Contents of $\mathrm{MgO}$ vary from $0.08-0.5 \mathrm{wt} \%$ and $\mathrm{CaO}$ from $0.14-0.48 \mathrm{wt} \%$, whereas those of $\mathrm{MnO}$ and $\mathrm{P}_{2} \mathrm{O}_{5}$ lie between 0.1-0.26 and 0.01-0.07wt \%, respectively. All samples have more $\mathrm{Na}_{2} \mathrm{O}$ than $\mathrm{K}_{2} \mathrm{O} . \mathrm{Na}_{2} \mathrm{O} / \mathrm{K}_{2} \mathrm{O}$ ranges from 2.0-4.92 for the radioactive veins and 1.42-1.86 for the granite and rhyolite.

Contents of $\mathrm{Al}_{2} \mathrm{O}_{3}, \mathrm{MgO}$ and $\mathrm{K}_{2} \mathrm{O}$ decrease from the granite and rhyolite to the radioactive veins, whereas those of $\mathrm{SiO}_{2}, \mathrm{Fe}_{2} \mathrm{O}_{3}$ and $\mathrm{Na}_{2} \mathrm{O}$-to- $\mathrm{K}_{2} \mathrm{O}$ increase. The negative covariance between silica and $\mathrm{Al}_{2} \mathrm{O}_{3}$ or $\mathrm{MgO}$ is consistent with some processes of magmatic differentiation such as crystallization fractionation. However, the $\mathrm{K}_{2} \mathrm{O}$ and $\mathrm{Na}_{2} \mathrm{O} / \mathrm{K}_{2} \mathrm{O}$ patterns deviate from their regular variation with silica during typical magmatic fractionation processes and, hence, $\mathrm{K}_{2} \mathrm{O}$ is low while $\mathrm{Na}_{2} \mathrm{O} / \mathrm{K}_{2} \mathrm{O}$ is high in the more silicic samples. These chemical deviations cannot be explained by crystal-liquid fractionation of 

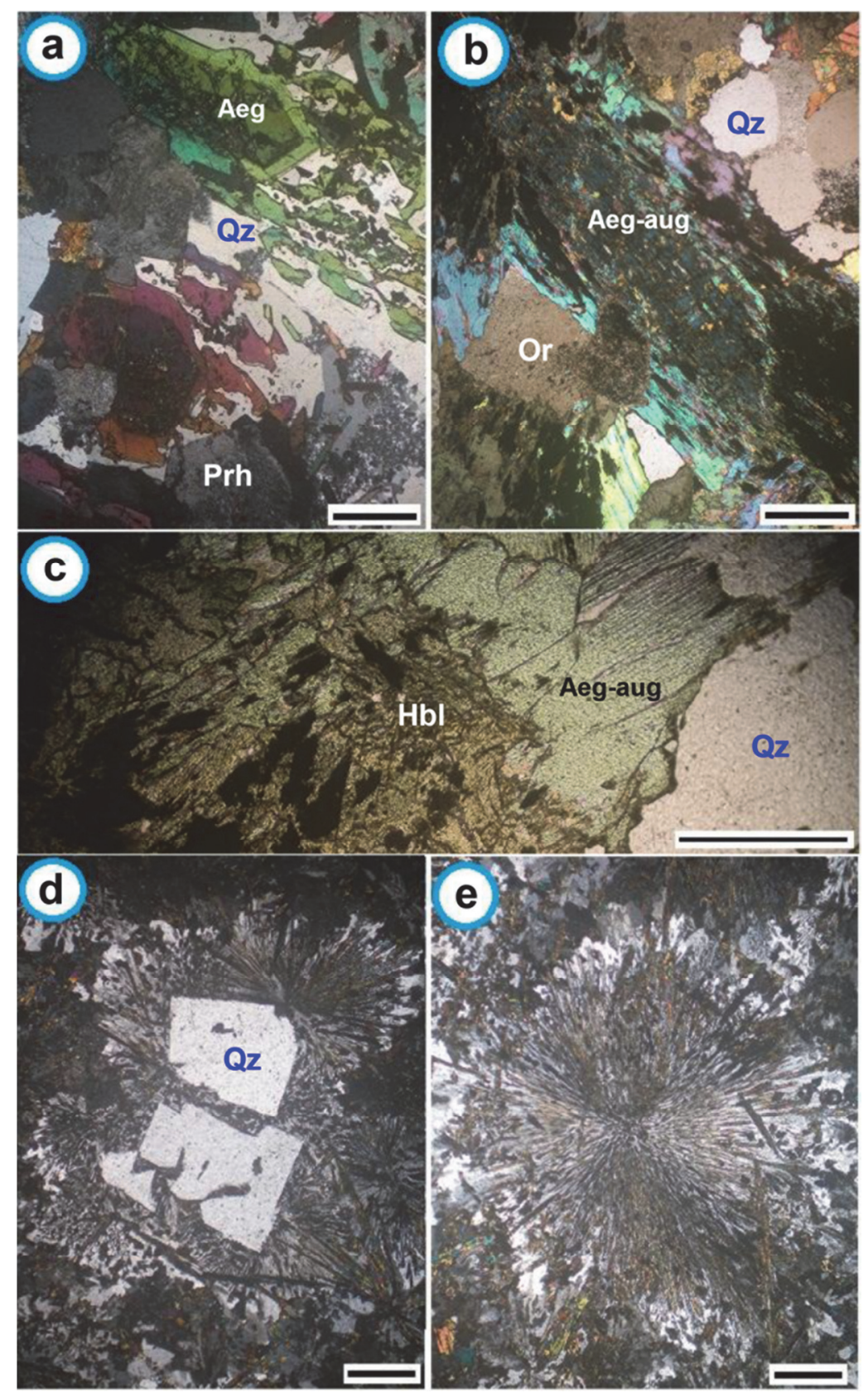

Fig. 3. Photomicrographs taken under crossed polars for granite samples G2 (a), G5 (b and c), rhyolite samples R2 (d) and R3 (e) from Seboah Hill (scale bar = 500 micrometers). The minerals present in alphabetical order: Aeg (aegirine), Aeg-aug (aegirine-augite), Hbl (hornblende), Or (orthoclase), Prh (perthite), (Qz) quartz. Note that (1) the aegirine-augite in photomicrograhs (b) and (c) is altered to riebeckite and hornblende, respectively and (2) the rhyolite photomicrograhs show spherulitic textures. 
the Seboah granite magma but require the evolution of sodium-enriched fluid. All samples analyzed for this study have a peralkalinity index (PAI $=$ mole $\left(\mathrm{Na}_{2} \mathrm{O}+\mathrm{K}_{2} \mathrm{O} / \mathrm{Al}_{2} \mathrm{O}_{3}\right)$ exceeding unity and, hence, are peralkaline, with values ranging from $\sim 1.4$ to $\sim 6$. The PAI values are much higher in the radioactive veins than in the granite and rhyolite. There is good correlation of PAI with $\mathrm{Na}_{2} \mathrm{O} / \mathrm{K}_{2} \mathrm{O}$ in all $(\mathrm{r}=+0.99)$.

In the $\mathrm{K}_{2} \mathrm{O}-\mathrm{Na}_{2} \mathrm{O}$ binary diagram (Fig. 4), the granite samples $\mathrm{G} 1, \mathrm{G} 4$ and $\mathrm{G} 5$ plot in the adamallite field of the Harpum (1963) granite classification. G2 lies on the adamallitegranodiorite boundary and G3 in the granodiorite field. G3 is a monzogranite and G1, G3, G4 and G5 are syenogranite, based on their modal quartz-alkaline feldspar-plagioclase compositions (Fig. 5).

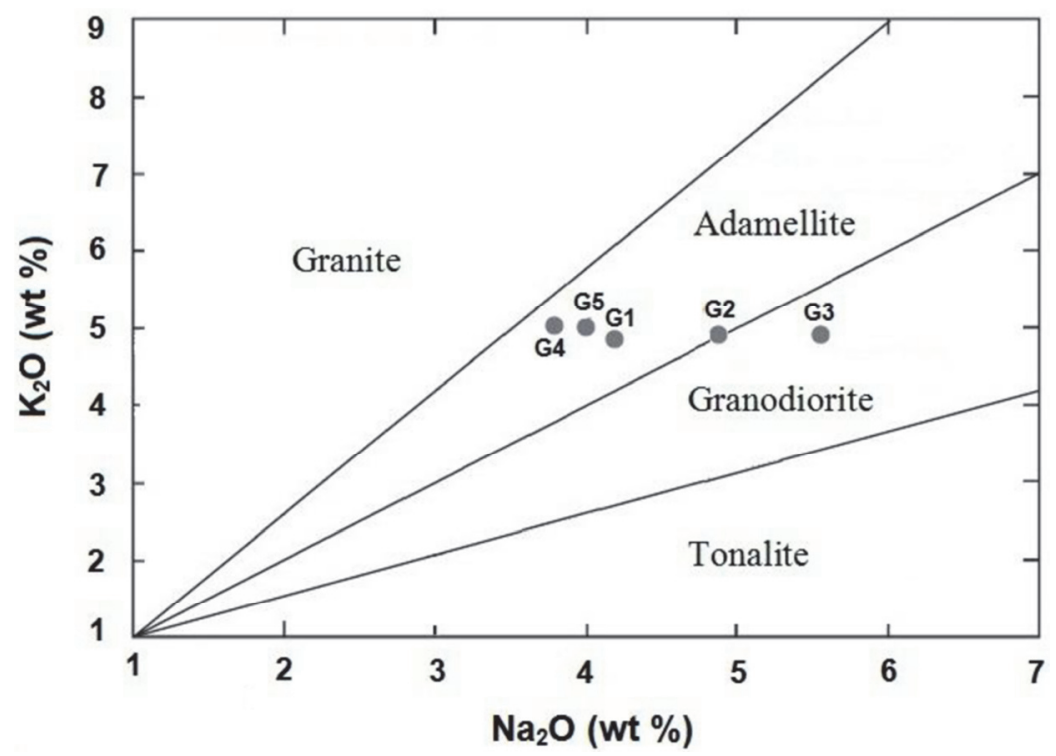

Fig. 4. Comparison of the Seboah granite on a plot of $\mathrm{K}_{2} \mathrm{O}$ versus $\mathrm{Na}_{2} \mathrm{O}$ after Harpum (1963).

The CIPW norms of all the Seboah Hill samples are given in Table 4. Most of the radioactive veins have higher normative Ac and Qz values than the granite and rhyolite. Normative hematite is invariably present $(0.22-6.12 \mathrm{wt} \%)$, with the radioactive veins having higher contents. The radioactive veins, granite, and rhyolite have overlapping values ( $\sim 99$ 98) of the fractionation index ( $\mathrm{FI}=\mathrm{QZ}+\mathrm{Or}+\mathrm{Ab}+\mathrm{Ac}+\mathrm{Ns})$. The samples have a low (55-78) differentiation index $(\mathrm{DI}=\mathrm{QZ}+\mathrm{Or}+\mathrm{Ab})$ with the radioactive veins having the lowest values. The FI and DI values together with varying trends of major-oxide elements support the conclusion that the radioactive veins and the granite of Seboah Hill are not related by a crystallization fractionation process. 


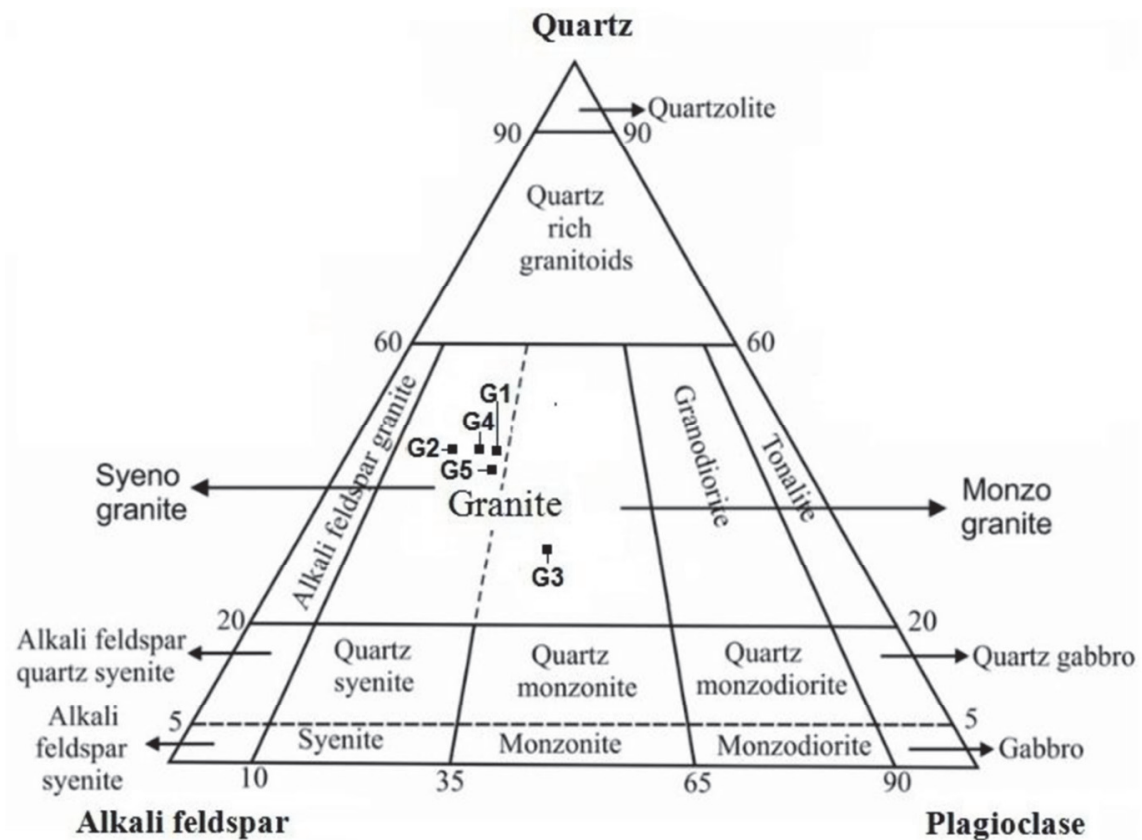

Fig. 5. Modal data of the Seboah granite plotted on the IUGS quartz-alkaline feldspar-plagioclase diagram of the plutonic rocks.

\subsection{Minor-element composition}

Minor-element data for all samples from Seboah Hill are listed in Table 5, as are the Clarke values for minor elements in the earth's crust from Mason (1966). The samples contain 52-307 ppm Ba, 0.5-8.6 ppm Co, 0.1-2.5 ppm Cs, 15-41.6 ppm Sr and 9-16 ppm V. The contents of these trace elements are depleted in the samples by factors of as low as $\sim 8$ to $\sim 50$ relative to the Clarke values. In the samples, $\mathrm{Ba}$ has a low correlation with the normative content of orthoclase $(\mathrm{n}=18 ; \mathrm{r}=+0.33)$ but exhibits a moderate correlation with normative albite $(\mathrm{n}=18 ; \mathrm{r}=+0.67)$. Barium is too large $\left(\mathrm{Ba}^{+2}-1.34 \AA\right)$ to substitute for calcium $\left(\mathrm{Ca}^{2+}-1.0 \AA\right)$ or sodium $\left(\mathrm{Na}^{+}-1.02 \AA\right)$, but it is comparable with potassium $\left(\mathrm{K}^{+1}-1.38 \AA\right)$ and, thus, should appear in micas and $\mathrm{K}$-feldspars in igneous rocks. However, strontium $\left(\mathrm{Sr}^{+2}-1.35 \AA\right)$ can be admitted into Ca-minerals or captured by K-minerals (Mason 1966). Here, granite G3 with the highest content of normative Ab has the highest $\mathrm{Ba}$ (and Sr) contents. Hassan (2005) has reported traces of barium sulfate in the radioactive veins. The correlation between the $\mathrm{Rb}$ content and the normative orthoclase of the samples is excellent $(\mathrm{n}=18 ; \mathrm{r}=0.98)$. As, generally, rubidium $\left(\mathrm{Rb}^{+1}-1.52 \AA\right)$ occupies some $\mathrm{K}^{+1}$ positions in feldspars, a decrease in the $\mathrm{K}$-feldspar content in a rock is associated with a decrease in this element and vice versa (Wedepohl 1974). This is the case here where the granite and the rhyolite samples, which are rich in K-feldspar, have contents of $\mathrm{Rb}$ from 163.8-201.3 ppm compared to $38.2-84.7 \mathrm{ppm}$ in the feldspar-poor radioactive veins. 
TABLE 4

Whole-rock major-element data for samples from Seboah Hill.

\begin{tabular}{|c|c|c|c|c|c|c|c|c|c|c|c|c|c|}
\hline & \multicolumn{6}{|c|}{ Radioactive veins } & \multicolumn{5}{|c|}{ Granite } & \multicolumn{2}{|c|}{ Rhyolite } \\
\hline & V1 & $\mathrm{V} 2$ & V4 & *V6 & V7 & V9 & G1 & $\mathrm{G} 2$ & G3 & G4 & G5 & R1 & R3 \\
\hline \multicolumn{14}{|c|}{ Oxides (wt $\%$ ) } \\
\hline $\mathrm{SiO}_{2}$ & 77.0 & 73.0 & 77.8 & 77.4 & 77.1 & 77.8 & 71.8 & 70.8 & 69.7 & 71.5 & 70.4 & 72.2 & 71.7 \\
\hline $\mathrm{TiO}_{2}$ & 0.18 & 0.3 & 0.18 & 0.33 & 0.33 & 0.27 & 0.48 & 0.31 & 0.5 & 0.29 & 0.30 & 0.38 & 0.28 \\
\hline $\mathrm{Al}_{2} \mathrm{O}_{3}$ & 2.80 & 1.81 & 1.96 & 1.6 & 1.6 & 1.73 & 8.10 & 7.08 & 9.9 & 8.10 & 8.51 & 7.52 & 7.19 \\
\hline $\mathrm{Fe}_{2} \mathrm{O}_{3}$ & 11.6 & 15.3 & 12.4 & 13.0 & 13.3 & 12.4 & 8.38 & 10.2 & 7.5 & 9.38 & 9.81 & 8.45 & 9.16 \\
\hline $\mathrm{MnO}$ & 0.24 & 0.25 & 0.18 & 0.19 & 0.19 & 0.19 & 0.19 & 0.18 & 0.18 & 0.10 & 0.17 & 0.26 & 0.10 \\
\hline $\mathrm{MgO}$ & 0.03 & 0.07 & 0.03 & 0.05 & 0.05 & 0.03 & 0.28 & 0.08 & 0.5 & 0.28 & 0.30 & 0.42 & 0.35 \\
\hline $\mathrm{CaO}$ & 0.14 & 0.24 & 0.30 & 0.24 & 0.24 & 0.2 & 0.25 & 0.28 & 0.48 & 0.21 & 0.31 & 0.27 & 0.14 \\
\hline $\mathrm{Na}_{2} \mathrm{O}$ & 4.4 & 5.9 & 3.8 & 3.01 & 3.14 & 3.51 & 4.18 & 4.85 & 5.56 & 3.78 & 4.05 & 4.47 & 3.97 \\
\hline $\mathrm{K}_{2} \mathrm{O}$ & 2.2 & 1.2 & 1.3 & 1.07 & 1.05 & 1.24 & 4.84 & 4.78 & 4.86 & 5.03 & 5.06 & 4.51 & 4.75 \\
\hline $\mathrm{P}_{2} \mathrm{O}_{5}$ & 0.1 & 0.04 & 0.01 & 0.05 & 0.05 & 0.05 & 0.03 & 0.03 & 0.07 & 0.02 & 0.03 & 0.01 & 0.01 \\
\hline LOI & 0.5 & 0.8 & 1.1 & 1.3 & 1.3 & 1.2 & 0.9 & 1 & 0.3 & 0.8 & 0.5 & 0.9 & 2.0 \\
\hline Total & 99.2 & 98.9 & 99.1 & 98.2 & 98.3 & 98.6 & 99.4 & 99.6 & 99.6 & 99.5 & 99.4 & 99.4 & 99.6 \\
\hline \multicolumn{14}{|c|}{ CIPW norms (wt\%) } \\
\hline Qz & 51.65 & 45.48 & 58.27 & 62.77 & 61.92 & 60.35 & 33.60 & 31.52 & 23.26 & 34.34 & 31.37 & 33.59 & 35.90 \\
\hline $\mathrm{Ab}$ & 2.18 & 2.68 & 2.90 & 2.34 & 2.46 & 2.05 & 14.96 & 9.94 & 24.07 & 13.86 & 15.78 & 13.80 & 10.79 \\
\hline Or & 13.17 & 7.23 & 7.84 & 6.52 & 6.39 & 7.52 & 29.07 & 28.65 & 28.97 & 30.16 & 30.24 & 27.10 & 28.75 \\
\hline Di & 0.03 & 0.38 & 0.16 & 0.28 & 0.28 & 0.17 & 0.83 & 0.44 & 1.61 & 0.72 & 1.06 & 1.10 & 0.04 \\
\hline Нy & 0.06 & & & & & & 0.33 & & 1.84 & 0.37 & 0.27 & 2.91 & 0.88 \\
\hline Wo & & 0.16 & 0.52 & 0.05 & 0.05 & 0.11 & & 0.11 & & & & & \\
\hline Ac & 31.31 & 42.47 & 26.36 & 21.08 & 21.95 & 25.05 & 18.50 & 27.91 & 18.60 & 16.38 & 16.63 & 20.38 & 20.80 \\
\hline Ns & & & & & & & & & 0.53 & & & 0.35 & \\
\hline Ilm & 0.35 & 0.55 & 0.35 & 0.42 & 0.42 & 0.42 & 0.93 & 0.39 & 0.96 & 0.56 & 0.58 & 0.73 & 0.22 \\
\hline Mag & 0.27 & & 0.07 & & & & 1.42 & & & 3.34 & 1.7 & & \\
\hline Hem & 0.75 & 0.90 & 3.50 & 6.12 & 6.12 & 4.07 & 0.31 & 0.70 & & 0.22 & 2.31 & & 2.19 \\
\hline Ap & 0.23 & 0.10 & 0.02 & 0.12 & 0.12 & 0.12 & 0.07 & 0.07 & 0.16 & 0.05 & 0.07 & 0.02 & 0.02 \\
\hline Tln & & 0.05 & & 0.29 & 0.29 & 0.14 & & 0.27 & & & & & 0.42 \\
\hline Total & 100 & 100 & 100 & 100 & 100 & 100 & 100 & 100 & 100 & 100 & 100 & 100 & 100 \\
\hline \multicolumn{14}{|c|}{ Geochemical parameters } \\
\hline$\%\left(\mathrm{Fe}^{3+} /\right.$ & 100 & 100 & 100 & 100 & 100 & 100 & 91 & 100 & 85 & 86 & 93 & 82 & 100 \\
\hline $\begin{array}{l}\Sigma \mathrm{Fe})^{\mathrm{a}} \\
\left(\mathrm{Na}_{2} \mathrm{O} /\right. \\
\left.\mathrm{K}_{2} \mathrm{O}\right)\end{array}$ & 2.0 & 4.92 & 2.92 & 2.81 & 2.99 & 2.83 & 0.86 & 1.01 & 1.14 & 0.75 & 0.8 & 0.99 & 0.84 \\
\hline $\mathrm{PAI}^{\mathrm{b}}$ & 3.43 & 6.06 & 3.91 & 3.82 & 3.96 & 4.11 & 1.50 & 1.86 & 1.46 & 1.44 & 1.42 & 1.63 & 1.62 \\
\hline $\mathrm{DI}^{\mathrm{c}}$ & 67 & 55.4 & 69.0 & 71.6 & 70.8 & 69.9 & 77.6 & 70.1 & 76.3 & 78.4 & 77.4 & 74.5 & 75.4 \\
\hline $\mathrm{FI}^{\mathrm{d}}$ & 98.3 & 97.9 & 95.4 & 92.7 & 92.7 & 95 & 96.1 & 98.0 & 95.4 & 94.7 & 94.0 & 95.2 & 96.2 \\
\hline
\end{tabular}

${ }^{\text {a }} \%\left(\mathrm{Fe}^{3+} / \Sigma \mathrm{Fe}\right.$ ) determined by Mëssbauer spectroscopy (See Text for references); ${ }^{\mathrm{b}}$ PAI (peralkalinity index $=$ mole $\left(\mathrm{Na}_{2} \mathrm{O}+\mathrm{K}_{2} \mathrm{O} / \mathrm{Al}_{2} \mathrm{O}_{3}\right) ;{ }^{\mathrm{c}}$ DI (differentiation index $=\mathrm{Qz}+\mathrm{Or}+\mathrm{Ab}$ ); ${ }^{\mathrm{d}} \mathrm{FI}$ (fractionation index $=\mathrm{Qz}+\mathrm{Or}+\mathrm{Ab}+\mathrm{Ac}+\mathrm{Ns})$. 
TABLE 5

Whole-rock minor-element data for samples from Seboah Hill and Clarke values of minor elements in the Earth's crust from Mason (1966).

\begin{tabular}{|c|c|c|c|c|c|c|c|c|c|c|c|}
\hline \multicolumn{11}{|c|}{ Radioactive veins } & \multirow{2}{*}{$\begin{array}{l}\text { Clarke values: } \\
\text { Earth's crust }\end{array}$} \\
\hline & V1 & $\mathrm{V} 2$ & V3 & V4 & V5 & V6 & V7 & V8 & V9 & V10 & \\
\hline \multicolumn{12}{|c|}{ Trace elements (ppm) } \\
\hline $\mathrm{Ba}$ & 105 & 115 & 119 & 188 & 179 & 143 & 142 & 144 & 147 & 150 & 425 \\
\hline $\mathrm{Be}$ & 11 & 8 & 11 & 22 & 14 & 22 & 14 & 17 & 14 & 12 & 2.8 \\
\hline Co & 0.8 & 0.6 & 1.3 & 0.9 & 0.5 & 1.1 & 1.3 & 1.4 & 1 & 1.2 & 25 \\
\hline Cs & 0.2 & 0.3 & 0.3 & $<0.1$ & 0.1 & 0.2 & 0.2 & 0.1 & 0.1 & 0.2 & 3 \\
\hline Ga & 20.7 & 12.7 & 11 & 12 & 12.1 & 11 & 10.5 & 8.6 & 11.7 & 11.2 & 15 \\
\hline $\mathrm{Rb}$ & 84.7 & 49.4 & 48.5 & 44.6 & 44.4 & 40.5 & 39.9 & 38.2 & 48.8 & 48.6 & 90 \\
\hline $\mathrm{Sr}$ & 29.8 & 24.9 & 23.2 & 16.5 & 15 & 27.7 & 28.5 & 30.1 & 26 & 28.7 & 375 \\
\hline V & $<8$ & 9 & $<8$ & $<8$ & $<8$ & $<8$ & $<8$ & $<8$ & $<8$ & $<8$ & 135 \\
\hline Y & 537 & 728 & 815 & 705 & 646 & 799 & 802 & 854 & 783 & 875 & 33 \\
\hline $\mathrm{Nb}$ & 1233 & 1078 & 1125 & 723 & 660 & 955 & 973 & 1067 & 1047 & 1209 & 20 \\
\hline $\mathrm{Ta}$ & 54.8 & 52.7 & 55.4 & 33.5 & 33.6 & 60 & 59 & 64.3 & 56.8 & 62.4 & 2 \\
\hline $\mathrm{Zr}$ & 1900 & 3482 & 3663 & 6055 & 6081 & 5699 & 5803 & 5612 & 4330 & 4437 & 165 \\
\hline Hf & 39.8 & 86.4 & 87.6 & 153 & 149 & 135 & 134 & 141 & 102 & 109 & 3 \\
\hline Th & 107 & 160 & 169 & 126 & 114 & 337 & 334 & 350 & 334 & 325 & 7.2 \\
\hline $\mathrm{U}$ & 21.4 & 56.3 & 58 & 33.8 & 30.6 & 37.9 & 36.7 & 42.3 & 45.5 & 48.3 & 1.8 \\
\hline \multicolumn{12}{|c|}{ Rare earth elements (REE) (ppm) } \\
\hline $\mathrm{La}$ & 845 & 939 & 1098 & 238 & 208 & 1254 & 1248 & 1410 & 1255 & 1433 & 30 \\
\hline $\mathrm{Ce}$ & 1578 & 1930 & 2061 & 503 & 416 & 3876 & 3876 & 4252 & 3132 & 3414 & 60 \\
\hline $\operatorname{Pr}$ & 188 & 214 & 226 & 37.5 & 33.2 & 388 & 384 & 412 & 330 & 336 & 8.2 \\
\hline $\mathrm{Nd}$ & 683 & 738 & 799 & 128 & 114 & 1362 & 1379 & 1514 & 1162 & 1293 & 28 \\
\hline $\mathrm{Sm}$ & 127 & 132 & 143 & 32.2 & 29.3 & 218 & 212 & 222 & 204 & 218 & 6 \\
\hline $\mathrm{Eu}$ & 15.4 & 17.4 & 18.7 & 5.29 & 5.11 & 22.9 & 23.4 & 24.6 & 24.1 & 26.4 & 1.2 \\
\hline Gd & 110 & 132 & 142 & 50.4 & 49.1 & 160 & 163 & 171 & 170 & 189 & 5.4 \\
\hline $\mathrm{Tb}$ & 15.9 & 20.9 & 22.5 & 11.6 & 10.9 & 23.2 & 24 & 24.3 & 24.7 & 27.2 & 0.9 \\
\hline Dy & 90.7 & 129 & 135 & 91.3 & 85.9 & 144 & 151 & 155 & 148 & 159 & 3 \\
\hline Но & 16.1 & 23.7 & 27.5 & 22.2 & 20.4 & 27.3 & 28.8 & 30.5 & 26.9 & 30.5 & 1.2 \\
\hline Er & 41.0 & 65 & 71.9 & 72 & 66.5 & 81.9 & 80.7 & 83.2 & 73.9 & 82 & 2.8 \\
\hline $\mathrm{Tm}$ & 5.37 & 9.2 & 9.73 & 11.1 & 10.3 & 11.5 & 11.7 & 12.3 & 10.6 & 11.6 & 0.5 \\
\hline $\mathrm{Yb}$ & 30.7 & 53.9 & 57.6 & 68.3 & 64.9 & 67.7 & 71 & 76.2 & 58.4 & 68.8 & 3.4 \\
\hline $\mathrm{Lu}$ & 3.94 & 7.68 & 7.95 & 10.2 & 9.94 & 9.52 & 9.91 & 10.5 & 7.98 & 8.93 & 0.5 \\
\hline$\sum \mathrm{REE}$ & 3750 & 4412 & 4820 & 1281 & 1124 & 7646 & 7663 & 8398 & 6628 & 7297 & 151 \\
\hline \multicolumn{12}{|c|}{ Ratios } \\
\hline $10^{4}(\mathrm{Ga}: \mathrm{Al})$ & 13.99 & 13.23 & & 11.53 & & 13.04 & 12.47 & & 12.85 & & \\
\hline $\mathrm{Rb}: \mathrm{Sr}$ & 2.84 & 1.98 & 2.1 & 2.7 & 2.96 & 1.46 & 1.4 & 1.3 & 1.88 & 1.69 & 0.24 \\
\hline Ce:La & 1.87 & 2.06 & 1.88 & 2.11 & 2 & 3.09 & 3.11 & 3.02 & 2.5 & 2.38 & 2 \\
\hline $\mathrm{Th} / \mathrm{U}$ & 5 & 2.84 & 2.91 & 3.73 & 3.82 & 8.89 & 9.1 & 8.27 & 7.34 & 6.73 & 4 \\
\hline$\left(\mathrm{Eu} / \mathrm{Eu}^{*}\right)^{\mathrm{a}}$ & 0.40 & 0.40 & 0.40 & 0.40 & 0.41 & 0.38 & 0.38 & 0.39 & 0.40 & 0.40 & 0.65 \\
\hline
\end{tabular}


TABLE 5 (continued).

\begin{tabular}{|c|c|c|c|c|c|c|c|c|c|}
\hline & \multicolumn{5}{|c|}{ Granite } & \multicolumn{3}{|c|}{ Rhyolite } & \multirow{2}{*}{$\begin{array}{l}\text { Clarke values: } \\
\text { Earth's crust }\end{array}$} \\
\hline & G1 & $\mathrm{G} 2$ & G3 & G4 & G5 & R1 & $\mathrm{R} 2$ & R3 & \\
\hline \multicolumn{10}{|c|}{ Trace elements (ppm) } \\
\hline $\mathrm{Ba}$ & 168 & 131 & 307 & 195 & 213 & 212 & 211 & 52 & 425 \\
\hline $\mathrm{Be}$ & 7 & 19 & 17 & 16 & 16 & 19 & 18 & 16 & 2.8 \\
\hline $\mathrm{Co}$ & 1.5 & 1.1 & 2.7 & 8.6 & 7 & 0.5 & 0.8 & 2.9 & 25 \\
\hline Cs & 0.6 & 0.2 & 0.5 & 2.3 & 2.5 & 0.4 & 0.2 & 1.6 & 3 \\
\hline $\mathrm{Ga}$ & 39.7 & 32.9 & 34 & 31.5 & 33 & 35.3 & 35.4 & 30.9 & 15 \\
\hline $\mathrm{Rb}$ & 163.8 & 165.3 & 169.5 & 181.8 & 194.3 & 201.3 & 206.4 & 201 & 90 \\
\hline $\mathrm{Sr}$ & 17.5 & 19 & 41.6 & 15.6 & 16.4 & 22.1 & 22.1 & 10.6 & 375 \\
\hline V & $<8$ & $<8$ & $<8$ & $<8$ & $<8$ & 16 & $<8$ & $<8$ & 135 \\
\hline Y & 222 & 153 & 195 & 206 & 274 & 299 & 321 & 168 & 33 \\
\hline $\mathrm{Nb}$ & 297 & 447 & 289 & 357 & 437 & 419 & 444 & 279 & 20 \\
\hline Тa & 21.8 & 13.3 & 18.6 & 17.9 & 18.2 & 27.4 & 27.3 & 16.9 & 2 \\
\hline $\mathrm{Zr}$ & 2948 & 858 & 2210 & 2870 & 2511 & 3229 & 3399 & 1838 & 165 \\
\hline Hf & 70.6 & 23.6 & 53.2 & 70.3 & 57.3 & 79.2 & 80 & 44.8 & 3 \\
\hline Th & 27.8 & 40.5 & 39.9 & 36.3 & 107 & 57.1 & 53.5 & 34 & 7.2 \\
\hline $\mathrm{U}$ & 12.7 & 5.0 & 10.6 & 11.7 & 15.2 & 15.1 & 16.5 & 8.4 & 1.8 \\
\hline \multicolumn{10}{|c|}{ Rare Earth elements (REE) (ppm) } \\
\hline $\mathrm{La}$ & 346 & 426 & 204 & 260 & 505 & 246 & 275 & 214 & 30 \\
\hline $\mathrm{Ce}$ & 536 & 775 & 397 & 453 & 892 & 565 & 639 & 431 & 60 \\
\hline $\operatorname{Pr}$ & 70.5 & 93.9 & 45.1 & 52.0 & 104 & 54.7 & 56 & 51.6 & 8.2 \\
\hline $\mathrm{Nd}$ & 264 & 334 & 160 & 179 & 374 & 187 & 207 & 196 & 28 \\
\hline $\mathrm{Sm}$ & 47.5 & 55.3 & 31.2 & 33.4 & 61.4 & 42.4 & 45.5 & 36.4 & 6 \\
\hline $\mathrm{Eu}$ & 5.97 & 6.51 & 4.94 & 5.3 & 9.22 & 6.37 & 6.6 & 3.55 & 1.2 \\
\hline $\mathrm{Gd}$ & 47.1 & 44.2 & 30.9 & 33.1 & 52.3 & 47.1 & 47.9 & 33 & 5.4 \\
\hline $\mathrm{Tb}$ & 6.38 & 5.9 & 5.12 & 5.23 & 7.7 & 8.29 & 8.25 & 5.09 & 0.9 \\
\hline Dy & 38.5 & 31 & 32.9 & 33.6 & 45.4 & 55 & 53.8 & 32.5 & 3 \\
\hline Ho & 7.62 & 5.69 & 7.21 & 6.65 & 9.3 & 10.8 & 11 & 6.42 & 1.2 \\
\hline $\mathrm{Er}$ & 21.1 & 13.9 & 20.1 & 18.0 & 25 & 30.5 & 31 & 18.2 & 2.8 \\
\hline $\mathrm{Tm}$ & 3.24 & 2.03 & 2.97 & 2.64 & 3.67 & 4.48 & 4.61 & 2.8 & 0.5 \\
\hline $\mathrm{Yb}$ & 21.5 & 12.3 & 19.7 & 16.7 & 24.3 & 27.6 & 29.4 & 18.4 & 3.4 \\
\hline $\mathrm{Lu}$ & 3.13 & 1.79 & 2.86 & 2.68 & 3.41 & 4.04 & 4.17 & 2.88 & 0.5 \\
\hline$\sum$ REE & 1419 & 1808 & 964 & 1101 & 2117 & 1289 & 1419 & 1052 & 151 \\
\hline \multicolumn{10}{|c|}{ Ratios } \\
\hline $10^{4}(\mathrm{Ga}: \mathrm{Al})$ & 9.26 & 8.88 & 6.43 & 7.37 & 7.37 & 8.88 & & 8.13 & \\
\hline $\mathrm{Rb}: \mathrm{Sr}$ & 9.36 & 8.7 & 4.08 & 11.65 & 11.85 & 9.11 & 9.34 & 19.96 & 0.24 \\
\hline $\mathrm{Ce}: \mathrm{La}$ & 1.55 & 1.77 & 1.94 & 1.74 & 1.72 & 2.3 & 2.32 & 2.01 & 2 \\
\hline $\mathrm{Th} / \mathrm{U}$ & 2.19 & 8.1 & 3.76 & 3.10 & 7.04 & 3.78 & 3.24 & 4.05 & 4 \\
\hline$\left(\mathrm{Eu} / \mathrm{Eu}^{*}\right)^{\mathrm{a}}$ & 0.39 & 0.40 & 0.49 & 0.49 & 0.53 & 0.44 & 0.43 & 0.31 & 0.65 \\
\hline
\end{tabular}

${ }^{\mathrm{a}}\left(\mathrm{Eu} / \mathrm{Eu}^{*}\right)$, the europium anomaly (see Text).

The radioactive vein, granite and rhyolite samples have overlapping contents (7-22 $\mathrm{ppm}$ ) of beryllium (Be) compared to the Clark value of $2.8 \mathrm{ppm}$ (see Table 5). However, they have distinct gallium ( $\mathrm{Ga}$ ) contents, namely, 8.6-20 ppm (radioactive veins) and 30.9$39.7 \mathrm{ppm}$ (granite and rhyolite). The Ga contents are correlated with the normative albite values $(\mathrm{r}=+0.87)$ and orthoclase $(\mathrm{r}=+0.97)$. Gallium $\left(\mathrm{Ga}^{+3}-0.62 \AA\right)$ with the same ionic charge and a radius close to that of aluminum $\left(\mathrm{Al}^{+3}-0.51 \AA\right)$, is likely camouflaged in 
aluminum-bearing minerals. The values of $\mathrm{Ga} / \mathrm{Al}$ of the radioactive vein samples vary from 11.5-13.9, whereas those of granite and rhyolite vary from 6.4-9.2 ppm. The low variations in $\mathrm{Ga} / \mathrm{Al}$ in the radioactive veins may indicate effective camouflage of $\mathrm{Ga}^{+3}$ in $\mathrm{K}$-feldspar.

The radioactive veins of Seboah Hill contain 1900-6081 ppm Zr, 660-1233 ppm Nb and 537-875 ppm Y. Contents of Th vary from $107-350 \mathrm{ppm}$ and Hf from 39.8-153 ppm, whereas those of $\mathrm{Ta}$ and $\mathrm{U}$ range from 33.5-64.3 and 21.4-58 ppm, respectively. Concentrations (ppm) of REE in these radioactive veins in decreasing order are: $\mathrm{Ce}=416$ 4252, $\mathrm{La}=208-1433, \mathrm{Nd}=114-1514, \mathrm{Pr}=33.2-412, \mathrm{Sm}=29.3-222, \mathrm{Gd}=49.1-189, \mathrm{Dy}=$ 85.9-159, $\mathrm{Er}=41-83.2, \mathrm{Yb}=30.7-76.2, \mathrm{Ho}=16.1-30.5, \mathrm{~Tb}=10.9-27.2, \mathrm{Eu}=5.11-26.4$, $\mathrm{Tm}=5.37-12.3, \mathrm{Lu}=3.94-10.5$. The granite and rhyolite, on the other hand, contain 858$3399 \mathrm{ppm} \mathrm{Zr}, 279-447 \mathrm{ppm} \mathrm{Nb}$, and 153-321 ppm Y. Contents of Th vary from 27.7-107 ppm and Hf from 23.6-80 ppm, whereas those of Ta and $\mathrm{U}$ range from 13.3-27.4 and 5-16.5 $\mathrm{ppm}$, respectively. The REE concentrations (in $\mathrm{ppm}$ ) of the granite and rhyolite in decreasing order are: $\mathrm{Ce}=397-892, \mathrm{La}=204-505, \mathrm{Nd}=160-374, \mathrm{Pr}=45.1-104, \mathrm{Sm}=$ 31.2-61.4, Dy $=31-55, \mathrm{Gd}=30.9-52.3$, Er (13.9-31), Yb (12.3-29.4), Ho (5.69-11), Eu (3.55-9.12), Tb (5.12-8.29), Tm (2.03-4.61), Lu (1.79-4.17). In the radioactive veins, the total concentrations of the 14-rare earth elements ( $\mathrm{REE}$ ) range from 1124-8398 ppm, compared to $964-1149 \mathrm{ppm}$ for the granite and rhyolite and the Clarke value of $151 \mathrm{ppm}$ (see Table 5).

Concentrations of $\mathrm{Zr}, \mathrm{Nb}, \mathrm{Y}$, Th, Hf, Ta, U, and the 14-rare earth elements (Table 5) are enriched in the radioactive veins by factors as high as 3.3-12.6 relative to the granite and rhyolite and by 21-71 relative to the Clarke values, respectively. These enrichments are not related to metasomatism by a $\mathrm{CO}_{2}$ volatile phase during or after emplacement; there is no carbonate present. Zirconium is the most abundant trace element in all samples and is followed by cerium. The contents of $\mathrm{Zr}$ are correlated with the contents of $\mathrm{La}, \mathrm{Nb}, \mathrm{Eu}, \mathrm{Sm}$, $\mathrm{Pr}, \mathrm{Nd}, \mathrm{Gd}, \mathrm{Ce}$ and $\mathrm{Tb}(\mathrm{r}=+0.42-+0.59)$, Ta, U, Th, Dy $(\mathrm{r}=+0.6-+0.69)$, Ho, Y $(\mathrm{r}=$ $+0.77-+0.78)$, Er, Tm, $\mathrm{Yb}, \mathrm{Lu}(\mathrm{r}=+0.85-+0.93)$ and $\mathrm{Hf}(\mathrm{r}=+1)$. The perfect positive correlation between $\mathrm{Zr}$ and $\mathrm{Hf}$ indicates that an increase or decrease in one always predicts the same directional change for the other. Hafnium $\left(\mathrm{Hf}^{4+}-0.78 \AA\right)$ chemically resembles zirconium $\left(\mathrm{Zr}^{4+}-0.79 \AA\right)$ and, thus, occurs combined in solid solution with $\mathrm{Zr}$ in natural specimens. In the radioactive vein, granite and rhyolite samples, the contents of $\mathrm{Ce}$ are correlated with those of Hf $(r=+0.51) \mathrm{U}, \mathrm{Lu}(\mathrm{r}=+0.68-+0.69)$, Nb, Y, Ta, Er, Tm, Yb, Ho $\left(\mathrm{r}^{=}+0.76-+0.89\right)$, Dy, Tb $(\mathrm{r}=+0.90-+0.92)$, Th, La, Gd, Eu $(\mathrm{r}=+0.95-+0.97)$, Sm ( $\mathrm{r}$ $=+0.99)$, $\operatorname{Pr}$ and $\mathrm{Nd}(\mathrm{r}=+1)$. High correlations $(\mathrm{r})$ between the contents of $\mathrm{Ce}$ and other elements reflect chemical similarities.

The radioactive veins and, to a lesser extent, the granite and rhyolite have high $\mathrm{Zr}$ contents though lacking any zircon mineralization. The absence of zircon is most likely a reflection of its stability in the peralkaline magma. The high excess of alkalis over alumina in peralkaline melts inhibits zircon formation (Whalen et al. 1987). In such melts, zircon solubility has been found to increase linearly with the peralkalinity index (PAI $=$ mole $\left.\left(\mathrm{Na}_{2} \mathrm{O}+\mathrm{K}_{2} \mathrm{O}\right) / \mathrm{Al}_{2} \mathrm{O}_{3}\right)$ with the amount of dissolvable $\mathrm{Zr}$ ranging up to $3.9 \mathrm{wt} \%$ at $\mathrm{PAI}=2$ (Watson 1979). For peraluminous melts and those lying in the Qz-Or-Ab plane composition, however, less than $100 \mathrm{ppm} \mathrm{Zr}$ is required for zircon saturation. This low $\mathrm{Zr}$ saturation level indicates that any felsic non-peralkaline magma is likely to precipitate zircon. Peralkaline granites with little or no zircon are known; they contain two or more of 
the Zr-silicates eudialyte, elpidite, armstrogite, and gittinsite (Table 1; Salvi, WilliamsJones 1995; Harris, Rickard 1987). Zircon is either scarce or absent in peralkaline syenites containing one or several sodium-potassium-calcium-iron silicates such as eudialyte, aenigmatite and astrophyllite (Table 1; Marks et al. 2011).

The radioactive veins of Seboah Hill contain anomalous levels of thorium (107$350 \mathrm{ppm}$ ) and uranium (21.4-58 ppm). The ratios of thorium to uranium in these range from 2.84-9.1, compared to 2.19-8.1 for the granite and 3.24-4.05 for the rhyolite (Table 5). Igneous rocks vary slightly in $\mathrm{Th} / \mathrm{U}$ values (Keevil 1944); most of the Seboah Hill samples fall in the range 3-4. Thus, high $\mathrm{Th} / \mathrm{U}$ ratios in the radioactive vein- and granite samples reflect retention of thorium and release of uranium during crystallization; hence thorium mineralization might be expected in the area. The contents of thorium of the radioactive veins, granite and rhyolite is strongly correlated with the cerium contents $(\mathrm{n}=18 ; \mathrm{r}=$ +0.95 ). This suggests that the two elements are largely linked by the same or indirectly related factors. Thorium $\left(\mathrm{Th}^{4+}-0.97 \AA\right)$ chemically resembles cerium $\left(\mathrm{Ce}^{4+}-1.03 \AA\right)$ and, thus, will tend to be present in solid solution combined with $\mathrm{Ce}$ in natural mineral assemblages.

Chondrite-normalized rare earth element (REE) distribution patterns for all the Seboah Hill, samples are given in Fig. 6. The normalized patterns for the radioactive veins (except V1, V4, and V5) are typical. V1 has a pattern of decreasing heavy REE abundances. V4 and V5, on the other hand, are depleted in light LREE, Gd, Tb and Dy. Their depletions may be attributed to the effect of hydrothermal alteration involving halogen-rich fluids. Redistributions of REE through water-rock interaction are common in hydrothermallyaltered rocks, particularly by fluids high halogen contents (see Dongen et al. 2010 and references therein). All the granite and rhyolite chondrite-normalized REE patterns are typical. The irregular parallelism of parts of the REE patterns for the radioactive veins, granite and rhyolite suggest that they are dominated by the same REE-bearing phases and, thus, have a common origin. The slopes of the light-REE patterns in the radioactive veins (excluding V4 and V5) and the granite and rhyolite suggest that the main phases contributing rare earth elements increase in light REE with depletion toward heavier REE. A study of REE and other rare elements in the radioactive veins by scanning electron microscopy-energy dispersive X-ray spectroscopy (Hassan 2005) showed the presence of trace $\mathrm{La}, \mathrm{Ce}, \mathrm{Th}, \mathrm{U}$ and $\mathrm{Nd}$ in aegirine. Many $\mathrm{REE}$ appear to reside in trace metal complexes including (1) Zr-Fe silicate with Ce, La, Nd, Th, Sm and U, (2) Zr-Fe-Y silicate with Ce, U, and Th, and (3) F-Zr-La-Nd silicate with Sm and Th.

The europium $(\mathrm{Eu})$ anomalies give another indication of the close genetic bond between all the radioactive vein, granite, and rhyolite samples of Seboah Hill revealed by the general similarities of their normalized REE patterns. Clearly, all have pronounced negative depletions in Eu relative to neighboring REE. These arise because crystallizing plagioclase takes up excess amounts of $\mathrm{Eu}^{2+}$ from its igneous source. $\mathrm{Eu} / \mathrm{Eu}^{*}$, where $\mathrm{Eu}$ is the measured europium and $\mathrm{Eu}^{*}$ is a predicted value for $\mathrm{Eu}^{3+}$ obtained by interpolation of the pattern of the other trivalent REE, defines the anomaly. Here, the geometric mean of the chondritenormalized Sm and Gd values, $(\mathrm{Sm} \times \mathrm{Gd})^{1 / 2}$, was used for $\mathrm{Eu}^{*}$ in calculating the anomalies. $\mathrm{Eu} / \mathrm{Eu}^{*}$ values for the radioactive veins vary from $0.38-0.41$ with a mean of 0.4 , while those for the granite and rhyolite vary from $0.31-0.53$ with a mean of 0.43 . The Eu/Eu values seem to suggest derivation from a common source, with some fractionation of Eu relative 
to other REE. The relatively high Eu variations observed in the granite and rhyolite are consistent with their variable composition, e.g. in their degree of oxidation and feldspar content. The extent of iron oxidation $(\% \mathrm{Fe} / \Sigma \mathrm{Fe})$ in the radioactive veins ranges from 82 $100 \%$ and the combined feldspar content (normative $\mathrm{Ab}+\mathrm{Or}$ ) from $39.54-53.04 \%$ (Table 4). In the radioactive veins, the Fe-oxidation intensity is $100 \%$ and the normative $\mathrm{Ab}+\mathrm{Or}$ content $8.85-15.35 \%$ (Table 4). Whole-rock Eu anomalies vary with fractionation in igneous systems crystallizing feldspar; they are controlled by melt crystal chemistry and redox potential (e.g. Towell et al. 1969).

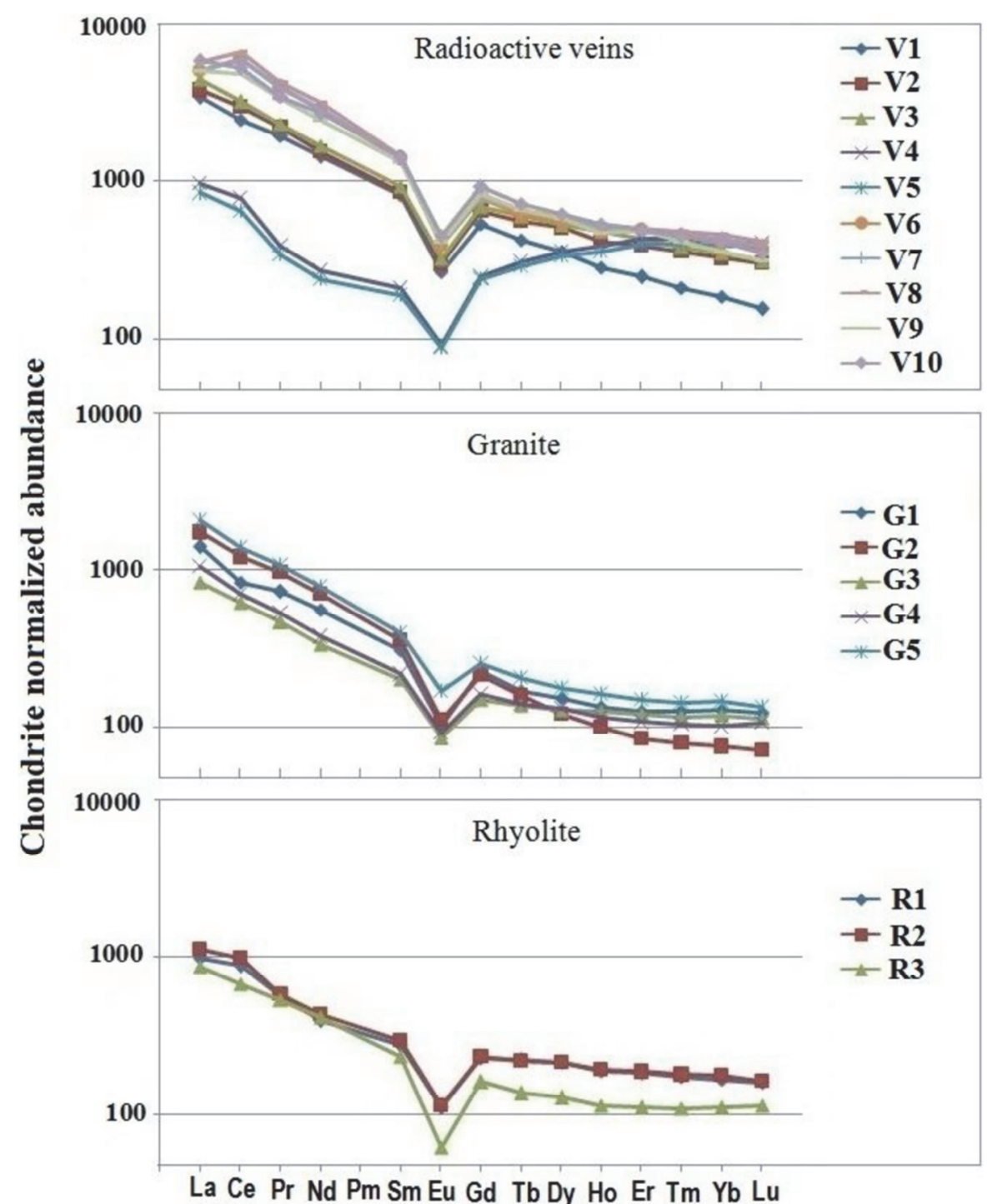

Fig. 6. Chondrite normalized REE patterns for the radioactive veins, granite and rhyolite samples of Seboah Hill (after Evensen et al. 1978). 


\section{Conclusion}

This study has focused on the major- and trace-element compositions of 18 representative samples of radioactive veins, granite and rhyolite from Seboah Hill in SW Egypt. The radioactive veins have high $\mathrm{Na} / \mathrm{K}$ in comparison to the granite and rhyolite; this cannot be explained by magmatic differentiation but requires a sodium fluid. Indices of fractionation and differentiation support the contention that the radioactive veins and the granite are not related by crystallization fractionation. Chemically, the radioactive veins are low in $\mathrm{Al}, \mathrm{Mg}, \mathrm{Ca}, \mathrm{K}, \mathrm{Cs}, \mathrm{Sr}, \mathrm{V}$ and $\mathrm{Rb}$, but enriched in silica, iron, $\mathrm{REE}$ and other rare metals. As much as 8398 ppm $\sum$ REE, 6081 ppm Zr, 1233 ppm Nb, 875 ppm Y, 350 ppm Th, $153 \mathrm{ppm} \mathrm{Hf}$, and $58 \mathrm{ppm} \mathrm{U}$ were measured in the radioactive veins. These enrichments appear to be incorporated into aegirine and to reside in trace silicate complexes. The overall similarity in REE patterns between the radioactive veins, the granite and the rhyolite suggest a genetic link.

Acknowledgments. The author wishes to acknowledge S. Woo and J.D. Chavez of Bureau Veritas Commodities Canada Ltd., Vancouver, Canada, for chemical analysis, E.M. Abuzeid of the Nuclear Materials Authority, Qattamia, Cairo, Egypt, for helping with the optical microscopy and D.S. Helman of Faculty of Labor Relations \& Trade Union, Ton Duc Thang University, Vietnam, for valuable discussions. Thanks are extended to the Editor-in-Chief (Marek Michalik), and two anonymous reviewers, who helped this manuscript reach a level of clarity satisfactory for publication.

\section{References}

Abdel Monem, H.M., \& El-Afandy, A.H. (1997). Geochemistry and beneficiation studies of U-Th bearing minerals of Um Risha complex, Eastern Desert, Egypt. Egyptian Mineralogist, 9, 43-58.

Andreeva, I.A. (2016). Genesis and mechanisms of formation of rare-metal peralkaline granites of the Khaldzan Buregtey massif, Mongolia: evidence from melt inclusions. Petrology, 24(5), 462-476. DOI: https://doi.org/10.1134/S0869591116050027.

Baioumy, H.M., Ismael,_I.S., \& Zidan, I.H. (2003). Clay mineralogy of the Nubia Formation, Western Desert (Egypt). Geologica Carpathica, 54(5), 329-336.

Das, U.K., Gantait, A., Panda, L., \& Hussain, S. (2016). Rare earth element potential of the felsite dykes of Phulan area, Siwana Ring Complex, Rajasthan, India. Current Science, 110(7), 1157-1162. DOI: 10.18520/cs/v110/i7/1157-1162.

Dongen, M.V., Weinberg, R.F., \& Tomkins, A.G. (2010). REE-Y, Ti, and P remobilization in magmatic rocks by hydrothermal alteration during $\mathrm{Cu}-\mathrm{Au}$ deposit formation. Economic Geology 105, 763-776. DOI: 10.2113/gsecongeo.105.4.763.

Egyptian Geological Survey and Mining Authority, 1981. Geological map of Egypt, scale 1:2,000,000. Abbasyia, Cairo, Egypt: Geological Survey and Mining Authority.

Evensen, N.M., Hamilton, P.J., \& O'nions, R.K. (1978). Rare earth abundances in chondritic meteorites. Geochimica et Cosmochimica Acta, 42, 1199-1212. DOI: https://doi.org/10.1016/00167037(78)90114-X.

Jain, R.S., Miglani, T.S., Kumar, S., Swarnkar, B.M., \& Singh, R. (1996). Rare metal and rare earth rich peralkaline, agpaitic granitoid dykes of Siwana ring complex, District Barmer, Rajasthan. Current Science, 70(9), 854-858.

Harris, C., \& Rickard, R. S. (1987). Rare-earth-rich eudialyte and dalyite from a peralkaline granite dyke at Strumsvola, Dronning Maud Land, Antarctica. Canadian Mineralogist, 25, 755-762.

Harpum, J.R. (1963). Petrographic classification of granitic rocks in Tanganyika by partial chemical analyses. Records of the Geological Survey of Tanganyika, 10, 80-86. 
Hassan, K.M. (2005). Geochemical assessment of radioactive lava pockets in El-Seboah granite, Toshki area, south Western Desert, Egypt. Annals of the Geological Survey of Egypt, 28, 195-204.

Hassan, K.M. (2009a). Rhyolite-dacite-trachyandesite association: a Mössbauer spectroscopy study. Hyperfine Interactions, 192, 101-107. DOI: https://doi.org/10.1007/s10751-008-9904-5.

Hassan, K.M. (2009b). Characterization of granites by ${ }^{57}$ Fe Mössbauer spectroscopy. Mineralogia, 40(1-4), 95106. DOI: https://doi.org/10.2478/v10002-009-0008-x.

Hassan, K.M. (2010). Valences and site characteristics of iron in radioactive magmatic veins (Egypt): A Mössbauer and chemical study. Mineralogia, 41(1-2), 23-33. DOI: https://doi.org/10.2478/v10002-0100003-2.

Hassan, K.M (2017). Mineralogical and geochemical signatures of silicified wood from the Petrified Forest, New Cairo, Egypt. The Canadian Mineralogist, 55,317-332. http://dx.doi.org/10.3749/canmin.1600089.

Keevil, B. 1944. Thorium-uranium ratios in rocks and minerals. American Journal of Science, 242, 309-321.

List, F.K., El-Gaby, S., \& Tehrani, R. (1989). The basement rocks in the Eastern and Western Deserts and Sinai. In M. Hermina, E., Klitzsch \& S. List (Eds.), Stratigraphic lexicon and explanatory note to the geologic map of Egypt 1:500000 (pp. 33-56). Cairo, Egypt: Egyptian General Petroleum Corporation.

Mc Birney, A.R. (1984). Igneous petrology. Freeman Cooper and Company, California.

Marks, M.A.W., Hettmann, K., Schilling, J., Frost, B.R., \& Markl, G. (2011). The mineralogical diversity of alkaline igneous rocks: critical factors for the transition from miaskitic to agpaitic phase assemblages. Journal of Petrology, 52, 439-455. DOI: https://doi.org/10.1093/petrology/egq086.

Mason, B. (1966). Principle of Geochemistry. Third edition. John Willey and Sons Inc., New York

Philpotts, J. A., Taylor, C.D., \& Baedecker, P.A. (1996). Rare-earth enrichment at Bokan Mountain, Southeast Alaska. In T. E. Moore \& J. A. Dumoulin (Eds.), Geologic studies in Alaska by the U.S. Geological Survey, 1994: U.S. Geological Survey, Bulletin 2152, 89-100.

Salvi, S., \& Williams-Jones, A. E. (1995). Zirconosilicate phase relations in the Strange Lake (Lac Brisson) pluton, Quebec-Labrador, Canada. American Mineralogist, 80, 1031-1040.

Sorokhtina, N.V., Kogarko, L.N., Shpachenko, A.K., Groznova, M.V, Kostitsyn, Yu.A., Roshchina, I.A., Gredina, I.V. 2012. Geochemistry and age of the complex of alkaline met somatic rocks and carbonadoes of the Gremyakha-Vyrmes Massif, Kola Peninsula. Geochemistry International. 50(12), 975-987.

Singh, A.K., \& Vallinayagam, G. (2009). Radioactive element distribution and rare-metal mineralization in anorogenic acid volcano-plutonic rocks of the Neoproterozoic Malani Felsic Province, Western Peninsular India. Journal of the Geological Society of India, 73, 837-853. DOI: https://doi.org/10.1007/s12594-0090067-z.

Towell, D.G., Spirn, R.V., \& Winchester, J.W. (1969). Europium anomalies and the genesis of basalt: a discussion. Chemical Geology, 4, 461-464. DOI: https://doi.org/10.1016/0009-2541(69)90012-6.

Watson, E.B. (1979). Zircon saturation in felsic liquids: experimental results and applications to trace element geochemistry. Contributions to Mineralogy and Petrology, 70, 407-419. DOI: https://doi.org/ 10.1007/BF00371047.

Whalen, J.B., Currie, K.L., \& Chappell, B.W. (1987). A-type granites: geochemical characteristics, discrimination and petrogenesis. Contributions to Mineralogy and Petrology, 95(4), 407-419. DOI: https://doi.org/10.1007/BF00402202.

Wedepohl, K.H. (1974). Handbook of geochemistry. Spring-Verlag, Berlin. 